\title{
The effect of applying institutional governance principles in the accounting disclosure of service companies listed on the ASE
}

\author{
Zeyad Almatarneh $^{\mathrm{a}^{*}}$, Abdelrahim Kadomi ${ }^{\mathrm{a}}$, Younes AIShobaki ${ }^{\mathrm{a}}$ and Ala Albawwat ${ }^{\mathrm{a}}$
}

${ }^{a}$ Faculty of Business Management, Amman Arab University, Jordan

\begin{tabular}{l}
\hline C H R O N I C L E \\
\hline Article history: \\
Received: March 31, 2021 \\
Received in revised format: \\
April 272021 \\
Accepted: May 22, 2021 \\
Available online: \\
May 22, 2021 \\
\hline Keywords: \\
Principles of institutional Govern- \\
ance \\
Accounting Disclosure \\
Amman Stock Exchange
\end{tabular}

\section{Introduction}

In the modern era, the world has witnessed an increasing interest in the principles of institutional governance in all countries of the world as a result of the financial crisis that occurred in them, as well as the bankruptcy and collapse of many banks and major companies, as their application has become an important issue worldwide, due to considering it the cornerstone of economic and banking development. A great deal of interest and concern for the supervisory and regulatory authorities, financial and economic organizations, the banking sector, companies, and institutions, whether at the regional or international level. Since 2004, efforts have focused on establishing governance that is concerned with different economic sectors, by creating a set of laws, principles, and legislations that work to impose more control over the behaviors of the board of directors and executive departments, as well as defining the objectives of institutions and the mechanism for achieving those objectives. Jordan is considered one of the developing countries in the world that is affected by various variables such as economic and political conditions, which may affect its economic situation in general and the performance of companies in particular. Based on the important and pivotal role of the Jordanian government in improving the level and efficiency of the economic sectors, especially the services sector, due to its close association with all other economic sectors, it is considered the most incomegenerating sectors and jobs and the most influential in growth and development, as it includes (education, transportation, tourism, health, trade, financial, and insurance services, and others), whether it is governmental or private, as it provides more than two-thirds of the national income in Jordan, due to depending on the main competitive element (the human element), all of the above mentioned makes it the first among the sectors in the value-added calculations, as considering it Jordan's oil that is inexhaustible (Al-Wazzani, 2019). In 2009, the Securities Commission issued instructions for corporate governance, as it

* Corresponding author.

E-mail address: zmatarneh@aau.edu.jo (Z. Almatarneh)

(C) 2021 by the authors; licensee Growing Science, Canada doi: $10.5267 / \mathrm{j} . \mathrm{ms} 1.2021 .5 .005$ 
was not obligated to apply the principles of governance, and in 2017 new instructions were issued binding on companies to apply the principles of governance, (Securities Commission, 2017). Hence, the study came to show the implications of applying the principles of institutional governance in the accounting disclosure for service companies listed on the Amman Stock Exchange (ASE) by focusing on the use of financial indicators to measure the extent to which the goals were achieved by defining the responsibilities of the board of directors to protect the interests of all parties and enhancing transparency in disclosure and dealings, thus increasing profits, minimizing losses, and uncovering abuses and irregularities.

\subsection{Study Statement}

The services sector is one of the most important economic sectors in Jordan (Al-Wazzani, 2019), and as a result of its exposure to control by boards of directors over the work of executive departments and control them, the need to apply institutional governance to this sector has necessitated to preserve it by setting principles and laws that adjust the relationship between board of directors, executive departments of the institutions, shareholders and other stakeholders that work to improve the financial performance by using financial indicators to measure the extent of achieving of the goals of these companies (Batayneh, Abd \& Sweden, 2019). Therefore, the study statement lies in an attempt to identify the effect of applying the principles of institutional governance on the accounting disclosure of service companies listed on the Amman Stock Exchange (ASE).

\subsection{Study Questions}

To achieve this purpose, the study will try to answer the following questions:

The main question: What is the impact of applying the principles of institutional governance using their instruments (board of directors' size, board of directors independence, and the concentration of ownership) on the accounting disclosure of service companies listed on the Amman Stock Exchange (ASE) with its indicators (return on assets and earnings per share)?

The main question stems from the following sub-questions:

1- The first question: What is the impact of applying the principles of institutional governance related to the board of directors' size on the financial performance of service companies in Jordan with its indicators (return on assets and earnings per share)?

2- The second question: What is the impact of applying the principles of institutional governance related to the board of directors' independence on the financial performance of service companies in Jordan with its indicators (return on assets and earnings per share)?

3- The third question: What is the impact of applying the principles of institutional governance related to the concentration of ownership on the financial performance of service companies in Jordan with its indicators (return on assets and earnings per share)?

\subsection{The Importance of Study}

The importance of the study is evident in two aspects, namely the theoretical side and the practical side:

\subsubsection{Scientific (Theoretical) Importance}

The scarcity of studies and research conducted on studying and analyzing the principles of institutional governance and their impact on accounting disclosure directly on service companies in Jordan, and it is hoped that the current study will enrich Arab and Jordanian libraries with theoretical and cognitive studies related to the principles of institutional governance, as well as studies related to the concept of accounting disclosure.

\subsubsection{Practical (Application) Importance}

It is hoped that the current study will provide the service sector companies with information about the relationship between the principles of institutional governance and accounting disclosure. It may also contribute to focusing on the process of separating tasks between the board of directors and executive department, and the provisions of supervision, thus ensuring the rights of shareholders and other stakeholders, and achieving the best results. It is hoped also that this study will open the way for researchers and those interested to conduct more studies and research on the principles of institutional governance and accounting disclosure from various other aspects.

\subsection{Study Hypotheses}

Based on the study statement and its questions, the following hypotheses were formulated: 
The main hypothesis (HO1): There is no statistically significant impact at the level of significance $(\alpha=0.05)$ to apply the principles of institutional governance (board of directors size, board of directors independence, and concentration of ownership) on the accounting disclosure of service companies in Jordan with its indicators (return on assets and earnings per share).

\section{The following sub-hypotheses emerge from the main hypothesis:}

Ho1-1 - The first hypothesis: There is no statistically significant impact at the level of significance $(\alpha=0.05)$ for the board of directors' size on the accounting disclosure of service companies in Jordan with its indicators (return on assets and earnings per share).

Ho1-2 - The second hypothesis: There is no statistically significant impact at the level of significance $(\alpha=0.05)$ for the board of directors' independence on the accounting disclosure of service companies in Jordan with its indicators (return on assets and earnings per share).

Ho1-3 - The third hypothesis: There is no statistically significant effect at the level of significance $(\alpha=0.05)$ of the concentration of ownership on the accounting disclosure of service companies in Jordan with its indicators (return on assets and earnings per share).

\subsection{Study model}

To achieve the purpose of this study and reach its objectives in determining the relationship between the independent and the dependent variable. The researcher built a hypothetical model for the study:

\begin{tabular}{|l|l|l|}
\hline \multicolumn{1}{|c|}{ Independent Variable } \\
\hline \multicolumn{1}{|c|}{ Institutional Governance } \\
Principles
\end{tabular}

Fig 1. Study Model

Source: Done by the researcher according to the previous references and studies, Al-Foley (2018), Shahwan \& Habib (2020), and Samour \& Dergham (2020)

\subsection{Procedural definitions}

Institutional governance: It is the system by which the company is directed and managed, which aims to define and achieve the goals of the company, to manage the company's business in a safe manner, to protect the interests of customers, to adhere to the due responsibility towards shareholders and other stakeholders, and the company adhere to the internal legislation and policies (Al-Aqra, 2019). It will also be measured by (board of directors' size, board of directors independence, and concentration of ownership). It is measured procedurally through the following variables:

1- Board of Directors Size: The size of the board represents the number of members participating in the company's board of directors, and the optimal size of the board of directors is between (7-8). Thus, large boards of directors are less effective than smaller ones because coordination, communication, and decision-making processes in a large board of directors are more difficult and complex than the ones occurring in a small board of directors. The board of directors should also take into account that the number of its members should be odd when forming, in order to ensure that decisions are taken by the majority or the alternative is to take into account that the chairman of the board of directors who has the carying vote is primarily an independent member (Brody \& Abdul Latif 2016).

2- Board of Directors Independence: It is the number of independent non-executive independent board of directors members at the date of the annual report divided by the total of members number of the board of directors, and they should not be linked to the company or its managers in a relationship that prevents them from performing their work in the required manner, in order to ensure that the independent members are able to play the role of control and follow-up for the executive department in a manner that meets the interests of the shareholders (Buertey 2019).

3- Concentration of ownership: The large percentage of shares owned by a small number of owners is known as concentration of ownership, and these owners own at least $5 \%$ of shares of the issuing company. This variable measures the impact of ownership concentration on performance, and it is measured by calculating the total percentage of major shareholders ownership who own 5\% of the company's shares, whether they are outside or inside the board of directors or the executive department of the company (Samour \& Dergham, 2020).

Accounting Disclosure: The accounting disclosure expresses business performance through financial indicators such as profitability, and it is the main support for the various businesses practiced by the company. It also measures the management's efficiency in utilizing resources optimally to make profits and then stating whether these profits are consistent in their results 
with the goals that the company seeks to achieve. It will be measured by (return on assets and earnings per share) (Shakkrat $\&$ Worship, 2020). It is measured procedurally through the following variables:

1- Return On Assets (ROA): It is the realized profit on per Dinar invested in the company's assets, and it reflects the efficiency of the company's management using the available resources to make profits, which means it measures the optimal use of assets and is calculated through the following (Kieso, Weygandt \& Warfield, 2020):

Return On Assets $=\frac{\text { Net Profit }}{\text { Average Total Assets }}$

2- Profitability Per Share (EPS): Is considered a key indicator of shares investment and as a measure of its order and differentiation between them, and the timing of this profit is subject to the company's policies in distribution and the nature of legislations in the country, in addition, it is included in one of the mathematical models for stock valuation and the ratio is calculated through the following: (Kieso, Weygandt \& Warfield, 2020)

Earnings Per Share $=\frac{\text { Net Income }}{\text { Weighted average of issued common stock number }}$

\section{Theoretical framework}

\subsection{Institutional governance}

The emergence of governance goes back in time. The theoretical and historical basis for governance goes back first to the Americans Berls \& Means in 1932, who published a book about the separation of company ownership from its management, and then the two American Nobel Prize winners for economics Jensen \& Meckling in 1976 came and presented what is called the theory of Realism Agency (Positive) where the managers are not the owners (Al-Nuaimi and Al-Ali, 2020, 54).

As a result of the large size of companies and the multiplicity of their activities and the complexity that followed in the business environment and the emergence of giant and transnational companies, thus, the owners of companies can no longer maintain the tasks of ownership and management combined, so due to that, they prompted to work on delegating the responsibility for making decisions to a specialized and capable administrative team in exchange for granting salaries, bonuses, and specific incentives, which led to the emergence of what is known as the agency theory (Samour \& Dergham, 2020; Nasr, 2020).

However, as a result of the excessive freedoms that are granted to managers and the absence of accurate control by employers, managers have become able to make decisions that would achieve their personal interests and satisfy their desires, as well as carry out activities that are not in the interest of the company or stakeholders, and these decisions and activities may lead to the collapse of the company (Al-Nuaimi and Al-Ali 2020).

\subsection{The concept of institutional governance}

The concept of the importance of applying the principles of institutional governance and the extent of its relevance to the financial performance of service companies has emerged through establishing the principles of transparency, accountability, justice, and the disclosure and control of accounting data and financial statements in order to reduce the manifestations of administrative and financial deficiencies (Al-Naimi \& Al-Ali, 2020, 56). Moreover, the importance of institutional governance also appears from another point of view in arranging roles clearly, improving the level of accountability, enhancing the professionalism of executive directors, which raises the value of the company, as well as working to reduce the spread of corruption, reduce the risks of economic crises, and improve the productivity of companies (Batayneh, Abd \& Sweden, 2019).

Definition of institutional governance: The definitions of institutional governance have varied widely, due to the reliance of one group on behavioral patterns such as (performance, efficiency, growth, financial structure,..etc.), and the other group relied on the normative framework such as (rules, laws, regulations, market,..etc).

- Institutional governance has been defined as a monitoring system that includes a set of rules, foundations, and principles working to improve and regulate the relationship between stakeholders (shareholders, employees, customers, government, lenders, and law) and the board of directors by defining the responsibilities of the board of directors in order to protect the interests of all parties, and enhance transparency in disclosure and dealings, thus, achieving the company's goals and limiting violations and abuses that may be committed by management (Al-Nuaimi \& Al-Ali, 2020, 57).

- The researcher believes that institutional governance determines the relationship between the board of directors and the executive departments, and between shareholders, stakeholders, and parties associated with the company such as (bondholders, workers, creditors, and citizens), within a set of mechanisms, procedures, laws, rules, regulations, decisions and standards, which include discipline, transparency and fairness, and it aims to achieve quality and excellence in performance by activating the actions of the company's management regarding the exploitation of the available economic resources, in a way that achieves the best possible benefits for all interested parties and society as a whole.

\subsection{The importance of applying the principles of institutional governance}

The importance of institutional governance has increased in the past few decades since it has been proven that good governance plays a major role not only in enhancing the performance of companies, but also in enhancing the financial and systemic stability of the company and it is also a means of creating trust and integrity in the company. Rational institutional governance 
is also considered to be of particular importance in reassuring shareholders and other stakeholders that their rights are protected from any violations that may occur from those in charge of managing the company, and the principles of institutional governance gain their importance through their support for economic development, raising investment rates and increasing investor and stakeholder confidence. Furthermore, the company ability to achieve its goals and protect it from risks and losses that may be exposed to, and which can be achieved by enhancing the efficiency of the company's management and its ability to make sound decisions based on a sound knowledge base, as well as providing a system of incentives and rewards so that it reflects positively on the services sector in general and the shareholders and stakeholders in particular (OECD, 2015).

\subsection{Institutional Governance Rules}

Institutional governance has a set of rules that are the main pillar of, which have been extracted from the principles of governance as follow: (Al-Nuaimi \& Al-Ali, 2020)

1- Disclosure and transparency: The governance framework should ensure accurate disclosure of all information, disclosure the ownership of the maximum ratio of shares, and disclosure related to members of the board of directors and executive directors. All the previous information shall be disclosed in a fair, impartial, honest, objectivity, honesty, and integrity manner among all shareholders and stakeholders in a timely manner and without delay, allowing for the preparation of useful analyzes of the company's operations, its economic fundamentals, and financial and non-financial information.

2- Accountability: Means accountability for the officials who make decisions and those who carry out the work in the company by evaluating and evaluating the work of the executive department and following them up to ensure that it carries out the tasks that would ensure that the work is done accurately by the rest of the employees in the company by submitting periodic reports on the results of the work and the extent of their success in implementing them.

3- Responsibility: It is the legal responsibility that relies on the board of directors through its supervisory role on the executive department and following up on its actions and the results of its work, as well as accountability of shareholders to the board of directors. All this is done through the distribution of powers and responsibilities within a clear organizational structure.

4- Justice: It means respecting and recognizing the rights of the various parties with interests in the company in a way that guarantees justice between them without prejudice to any group or category, and the distribution of tasks, duties, and responsibilities among all employees in the company on the basis of justice and equality.

5- Independence: It means the absence of material or administrative influences and pressures that may affect decisionmakers through the formation of boards that contain independent members and their participation in the committees emanating from, as well as the appointment of the external auditor so that there is no external influence or authority on the board of directors' decisions or company business.

6- Integrity: It means the existence of financial and ethical integrity, which governance focuses on, that are applied through the provisions related to internal and external control, and this is what the company seeks to achieve through institutional governance.

The researcher believes that governance brings credibility and fairness to the financial statements prepared by the management of companies that many parties rely on in making their economic decisions. Therefore, the matter requires that the auditor have the necessary skills and knowledge that enable him to carry out his role efficiently and work to continuously develop his capabilities so that he can Keep up with the continuous and accelerating changes in the environment in which he operates.

\subsection{Disclosure and Transparency}

Good disclosure and transparency in presenting financial and non-financial information are one of the main principles and pillars that governance is based on. Accordingly, no report by an organization, body, or scientific study was issued without included prejudice to the role of governance in achieving disclosure and transparency, especially since they are effective methods to achieve the interests of the various parties involved. It also represents one of the important indicators for judging whether or not the governance system is implemented within the various companies. Likewise, the principles of governance must include accurate and timely disclosure of all important matters related to economic units, regarding their financial position, in addition to the financial, operational, and monetary performance, and other aspects related to members of the board of directors and senior management (Rashwan, 2017).

\subsection{Concept of accounting disclosure}

The accounting disclosure is the apparent visual behavior that can be observed, appreciated, and evaluated. Performance represents success, which means, an mark of successful representation, this mark may change along with the change of organizations, or their workers, or their material and technical capabilities, and it can be considered the ability of the organization to achieve its goals through the use of available resources In an efficient and effective manner (Al-Qahtani, 2015).

Accounting disclosure is defined as the process by which a set of quantitative and qualitative indicators are explored and derived about the activity of any economic project concerned with determining the importance and characteristics of the 
operational and financial activities of the project through information used from the financial statements and other sources in order to use these indicators in evaluating financial performance (Shakhatrah \& Obada, 2020).

The researcher defines financial performance as measuring the extent of achieving financial goals by indicators provided by financial analysis in comparison between current performance and expected performance, thus, knowing the strengths and weaknesses that affect the value of the company.

\subsection{Criteria for evaluating financial performance}

In the financial analysis, the importance of determining the criteria that are used to follow the change of financial indicators is highlighted, because judging the nature of their change from year to year depends mainly on the possibility of comparing them with other standards, and most importantly of these criteria (Chakkara \& Worship, 2020):

1- Historical criteria: They are criteria derived from the company's past performance so that the financial analyst can calculate the financial indicators from the financial statements by measuring them in comparison with the past years for the purpose of monitoring the performance of the current year.

2- Sectoral criteria: They are performance criteria derived from the service sector to which the company's mechanism belongs, and they refer to the performance rate of a group of companies in that sector.

3- Absolute criteria: This one reflects some of the prevailing traditions or legislations in this regard so that some of them stem from international criteria, and they are reflected in the existence of a set of standards (financial ratios) that are generally accepted and derived from scientific experiences.

4- Targeted criteria: These are criteria that the company works to achieve through its strategies, policies, plans, and budgets so that moving away from them or not achieving them means deviating from the required performance.

\section{Related Previous Studies}

\subsection{Studies in Arabic}

Al-Zoubi's study (2016), which aimed to identify the impact of the application of institutional governance rules in Jordanian commercial banks regarding irregular risks. In order to achieve the objectives of the study, the researcher relied on the analytical descriptive approach which aims to describe certain phenomena or events and analyze their impact on the characteristic of non-systemic risks. The study population consisted of (13) Jordanian commercial banks, and the study sample consisted of all the vocabulary of the study population. The study found that an increase in the board of directors size and the separation of duties lead to an increase in credit risk and an increase in operational risks, accordingly an increase in the independence ratio of the board of directors leads to a reduction in credit risk and an increase in liquidity risk and an increase in operational risks. The study recommended the necessity of working on strengthening the independence of the board of directors' members by the banks due to its important role in reducing credit risk.

Batayneh, Abd \& Sweden (2019) study, which aimed to test the effect of ownership structure (family and non-family) and institutional governance on the financial performance of Jordanian industrial and service companies listed on the Amman Stock Exchange. Institutional governance was measured by the board of directors size, members ownership of the company's shares, the independence, the academic level of the members, and the combination between the positions of the chairman, the executive director, and the institutional ownership. On the other hand, the Tobin index was used for financial performance. The study sample consisted of (92) industrial and service public shareholding companies listed on the Amman Stock Exchange during the period from 2010 to 2014, divided into (58) family companies and (34) non-family companies. The study found a statistically significant effect of the ownership structure and institutional governance on the financial performance of all the sample companies measured by the Tobin index. The study also recommended that public shareholding companies and family companies should abide by the governance instructions issued by the Jordan Securities Commission.

The study of Salihat, Shabita, Zaabi \& Al-Omari (2020), which aimed to demonstrate the impact of the board of directors' structure on the quality of the profits of Jordanian commercial banks. The study sample consisted of all Jordanian commercial banks during the period from 2009 to 2016, where several statistical models were used. The study concluded that there is no statistically significant effect of the board of directors' structure on the quality of profits, as well as there is no statistically significant effect of the board of directors size on the quality of profits, but there is a statistically significant effect of separating tasks on profits, and there is a statistically significant difference for the effect of adherening the rules of the board of directors structure and its composition on the quality of commercial bank profits according to the size of the bank. The study also recommended the necessity of strengthening institutional governance instructions and increasing control by the central bank and regulatory bodies.

Samour and Dergham's study (2020), which aimed to identify the effect of the ownership structure components (focusing on ownership, board of directors' ownership, institutional ownership, and foreign ownership) regarding agency costs. The study sample consisted of All the 6 banks listed on the Palestine Stock Exchange during the study period from 2009 to 2018, and the researcher relied on the fixed effects method of analyzing thesectional data over time, and the multiple regression analysis methods to test the study hypotheses. The study concluded a positive effect for each variable of concentration of ownership and ownership of the board of directors regarding agency costs in banks listed on the Palestine Stock Exchange, and there is 
a negative effect of institutional ownership variable regarding agency costs, and there is no effect of the foreign ownership variable regarding agency costs. The study recommended the necessity of increasing attention to institutional ownership and strengthening it by selecting their experienced and competent representatives and developing regulator instruments.

\subsection{Studies in English}

A study (Buertey, Sun, Lee, and Hwang, 2019), which aimed to investigate the relationship between corporate social responsibility, profit management, and the role of institutional governance mechanisms in influencing social responsibility and profit management. The sample of the study consisted of non-financial institutions in Johannesburg Stock Exchange for the period from 2012 to 2015, where the researcher relied on the use of a descriptive statistical model and a bivariate correlation matrix, and also a multivariate regression analysis was used. The study concluded that there is a positive effect of institutional governance on companies social responsibility, which means that an increase in the number of people in the board of directors leads to an increase in the performance of social responsibility, and there is also a positive effect of the correlation between the independence of the board of directors and the companies social responsibility. The study recommended that the greater the percentage of independent directors in the company's board of directors, the greater the possibility of curbing any harmful administrative use of companies' social responsibility as a form of securing a reputation for engaging in emerging markets.

ALtawalbeh (2020) study, which aimed to investigate the impact of institutional governance mechanisms on the company's performance. Institutional governance practices were divided into two groups (Board of directors structure and ownership structure). The study sample consisted of (60) companies from the industrial and service sectors in Amman, listed on the stock exchange for the period from 2012 to 2017, where statistical programs Stata were used to conduct tests of the study hypotheses. The study concluded that the frequency of board of directors meetings has a role in enhancing the quality of decision-making, thus, has a significant positive impact on the company's performance, and there is a positive impact of government ownership on the company's performance. The study recommended the importance of choosing independent board of directors members able to carry out activities effectively, and also that the control function should be strengthened in order to improve the company's performance.

Shahwan \& Habib (2020) study, which aimed at assessing the efficiency of institutional governance practices and intellectual capital and exploring their impact on the potential of financial hardship of the company. The relative efficiency of governance and intensive care practices were measured according to the Malmquist Data Cover Analysis model. The sample of the study consisted of (51) industrial companies that were traded in the Egyptian Stock Exchange for the period from 2014 to 2016. The study concluded that there is no effect of the efficiency of institutional governance practice on the possibility of financial distress, while there is a negative effect of the intellectual capital efficiency on the probability of financial hardship. The study recommended that the Egyptian legislative authority should find ways to ensure strict control over companies' commitment by adhering the best practices in institutional governance mechanisms, by imposing a mandatory law on companies.

\section{Methodology}

Based on the study nature and its objectives that it seeks to achieve, the researcher used the analytical descriptive approach.

\subsection{Study Population and Sample}

The study population consisted of all service companies in Jordan, numbering (170) companies, and the study sample will consist of (14) companies distributed into two important sectors, the education sector which includes (6) companies and the transport sector which includes (8) companies. The education sector is one of the most important service sectors for the national economy, due to the role of education in increasing the rates of growth and economic development, as well as providing the various sectors with the labor element, or the so-called human capital, (Khudair, 2020). As for the transport sector, it is considered the first lever for the growth and development of the economic situation, in addition to its role in accelerating the transport of people and goods and linking the governorates to each other (Barmawi, 2019).

The Amman Financial Market was credited to obtain financial data related to the education sector and the transport sector.

\section{Table 1}

Done by the researcher based on Amman Exchange Stock

\begin{tabular}{llll}
\hline \multicolumn{2}{l}{ Education Sector } & Transport Sector \\
\hline Number & Company Name & Number & Company Name \\
$\mathbf{1}$ & The Arab International For Education \& Investment. & 1 & Royal Jordanian \\
$\mathbf{2}$ & Al-Zarqa Educational \& Investment & 2 & Rum Group For Transportation \& Tourism Investment \\
$\mathbf{3}$ & Petra Education Company & 3 & Masafat For Specialised Transport \\
$\mathbf{4}$ & Al Ittihad Schools & 4 & Salam International Transport \& Trading \\
$\mathbf{5}$ & Al-Isra For Education And Investment "PLC" & 5 & Jordan National Shipping Lines \\
$\mathbf{6}$ & Philadelphia International Educational Investment Company & 6 & Comprehensive Multiple Transportations CO. \\
& & 7 & Transport \& Investment Barter Company \\
& & 8 & Jordan Express Tourist Transport/JETT \\
\hline
\end{tabular}




\subsection{Study Instruments}

The study data were collected by reviewing the financial reports published on the Amman Stock Exchange for the period (2014-2019). The study variables were calculated for these reports to measure the effect of the independent variable (the principles of institutional governance with its dimensions) on the indicators of the dependent variable (return on assets and earnings per share).

\subsection{Used Statistical Methods}

The data obtained by analyzing the financial statements of the study sample was processed according to the tests that achieve the purpose of the study, and specifically, the following methods were used: Analysis of variance (ANOVA): It aims to test the differences between different groups and then improve the ability to make important comparisons between the different groups. Simple linear regression analysis (Multiple Regression): It aims to identify the level of common variance between two variables as if the rise or reduction in the independent variable is followed by a rise or reduction in the dependent variable.

\section{Results}

\subsection{Test the first main hypothesis}

$\mathrm{H}_{\mathrm{O} 1}$ : There is no statistically significant impact at a significant level $(\alpha=0.05)$ to apply the principles of institutional governance (board of directors' size, board of directors' independence, concentration of ownership) on the accounting disclosure of service companies in Jordan with its indicators (return on assets (ROA), earnings per share. (EPS)).

\section{This hypothesis was tested in two stages:}

The first stage: Examining the impact of applying the principles of institutional governance (board of directors' size, board of directors' independence, concentration of ownership) on the accounting disclosure of service companies in Jordan with the return on assets (ROA) index, using multiple linear regression, accordingly the following results were concluded:

\section{Table 2}

Results of multiple regression to test the impact of applying the principles of institutional governance (board of directors' size, board of directors' independence, concentration of ownership) on the accounting disclosure of service companies in Jordan with the indicator (return on assets ROA)

\begin{tabular}{lccccccc}
\hline Independent factors & t value & t Sig. & Standardized $\beta$ eta & R & R $^{2}$ & F value & F Sig. \\
\hline Board of directors' size & 4.998 & .001 & .596 & & & \\
Board of directors' independence & .000 & 1.000 & .000 & $.988^{\mathrm{a}}$ & .976 & 134.095 & $.000^{\mathrm{a}}$ \\
Concentration of ownership & 2.828 & .018 & .421 & & & & \\
\hline
\end{tabular}

a. Dependent Variable: ROA

b. Predictors: (Constant), Number of owners, Independent members, board of directors' size

Table 2 shows the following:

- There is statistically significant impact of board of directors' size on return on assets at the significance level $(\alpha \leq 0.05)$, where (t) value was $(4.988)$, by Sig. $(p=.001)$, and with an interpretation ratio $(59.6 \%)$, which represents the value of (ßeta).

- There is no statistically significant impact of board of directors' independence on return on assets at the significance level $(\alpha \leq 0.05)$, where $(\mathrm{t})$ value was $(0.000)$, by Sig. $(p=1.000)$.

- There is statistically significant impact of ownership concentration on return on assets at the significance level $(\alpha \leq 0.05)$, where (t) value was (2.828), by Sig. $(p=.018)$, and with an interpretation ratio (42.1\%), which represents the value of (ßeta).

The Second stage: Testing the impact of applying institutional governance principles (board of directors' size, board of directors' independence, concentration of ownership) on accounting disclosure of service companies in Jordan with a (EPS) index (eps) by using (Multiple Linear Regression) accordingly the following results were concluded:

\section{Table 3}

Results of multiple regression to test the impact of applying the principles of institutional governance (board of directors' size, board of directors' independence, concentration of ownership) on the accounting disclosure of service companies in Jordan with the indicator (earnings per share (EPS))

\begin{tabular}{cccccccc}
\hline Independent factors & t value & t Sig. & Standardized $\beta$ eta & R & R $^{2}$ & F value & F Sig. \\
\hline Board of directors' size & 2.427 & .036 & .642 & & & & \\
Board of directors' independence & .398 & .699 & .070 & $.938^{\mathrm{a}}$ & .881 & 24.603 & $.000^{\mathrm{a}}$ \\
Concentration of ownership & .845 & .418 & .279 & & & & \\
\hline
\end{tabular}

a. Dependent Variable: EPS

b. Predictors: (Constant), Board of directors' size, Board of directors' independence, concentration of ownership 
Table 2 shows the following:

- There is statistically significant impact of board of directors' size on earnings per share at the significance level $(\alpha \leq 0.05)$, where (t) value was (2.457), by Sig. $(p=.036)$, and with an interpretation ratio (64.2\%), which represents the value of (ßeta).

- There is no statistically significant impact of board of directors' independence on earnings per share at the significance level $(\alpha \leq 0.05)$, where $(\mathrm{t})$ value was $(0.398)$, by Sig. $(p=0.699)$.

- There is no statistically significant impact of ownership concentration on earnings per share at the significance level $(\alpha \leq 0.05)$, where (t) value was $(0.845)$, by Sig. $(p=0.418)$.

\subsection{The first sub hypothesis}

HO1: There is no statistically significant effect at the level of $(\alpha=0.05)$ of the board of directors' size on the accounting disclosure of service companies in Jordan with its indicators (return on assets (ROA), earnings per share (EPS).

\section{This hypothesis was tested in two stages:}

The first stage: Examining the effect of the board of directors' size on the accounting disclosure of service companies in Jordan with the indicator (return on assets (ROA), using the simple linear regression test, and the following results were concluded:

Table 4

Results of simple linear regression to test the impact of board of directors' size effect on return on assets (ROA) indicator

\begin{tabular}{cccccccc}
\hline t value & t Sig. & Standardized & $\beta$ eta & R & $\mathbf{R}^{\mathbf{2}}$ & F value & F Sig. \\
\hline 13.352 & .000 & .968 & $.968^{\mathrm{a}}$ & .937 & 178.286 & $.000^{\mathrm{a}}$ \\
\hline
\end{tabular}

a. Dependent Variable: ROA

b. Predictors: (Constant), Board of directors' size

Table 4 shows that there is statistically significant impact of board of directors' size effect on accounting disclosure of service companies in Jordan by return on assets (ROA) indicator at the significance level $(\alpha \leq 0.05)$, where ( $t)$ value was $(13.352)$, by Sig. (0.000).

The second stage: Examining the impact of the board of directors' size on the accounting disclosure of service companies in Jordan with an index (earnings per share EPS), using the simple linear regression.

Table 5

Results of simple linear regression to test the impact of board of directors' size effect on earnings per share (EPS) indicator

\begin{tabular}{|c|c|c|c|c|c|c|}
\hline t value & t Sig. & Standardized $\beta$ eta & $\mathbf{R}$ & $\mathbf{R}^{2}$ & F value & F Sig. \\
\hline 8.198 & .000 & .921 & $.921^{\mathrm{a}}$ & .848 & 67.200 & $.000^{\mathrm{a}}$ \\
\hline
\end{tabular}

Table 5 shows that there is statistically significant impact of board of directors' size effect on accounting disclosure of service companies in Jordan by earnings per share (EPS) indicator at the significance level $(\alpha \leq 0.05)$, where $(t)$ value was $(8.198)$, by Sig. (0.000).

\subsection{The second sub-hypothesis}

$\mathrm{H}_{\mathrm{O} 1-2}$ : There is no statistically significant impact at the level of $(\alpha=0.05)$ for the board of directors' independence on the accounting disclosure of service companies in Jordan with its indicators return on assets (ROA) and earnings per share (EPS).

\section{This hypothesis was tested in two stages:}

The first stage: Examining the effect of the board of directors' independence on the accounting disclosure of service companies in Jordan with the indicator return on assets (ROA), using the simple linear regression test, and the following results were concluded:

\section{Table 6}

Results of simple linear regression to test the impact of board of directors' independence effect on return on assets (ROA) indicator

\begin{tabular}{rrrrrrrr}
\hline t value & t Sig. & Standardized & $\beta e t a$ & R & $\mathbf{R}^{\mathbf{2}}$ & \multicolumn{1}{c}{ F value } & F Sig. \\
\hline 2.461 & .030 & .579 & .579 & .335 & 6.056 & .030 \\
\hline
\end{tabular}

a. Dependent Variable: ROA

b. Predictors: (Constant), board of directors' independence 
Table 6 shows that there is statistically significant impact of board of directors' independence effect on accounting disclosure of service companies in Jordan by return on assets (ROA) indicator at the significance level $(\alpha \leq 0.05)$, where (t) value was (6.056), by Sig. (0.030).

The second stage: Examining the impact of the board of directors' independence on accounting disclosure of service companies in Jordan with earnings per share (EPS) index by using the simple linear regression test, and the following results were concluded:

Table 7

Results of simple linear regression to test the impact of board of directors' independence impact on earnings per share (EPS) index

\begin{tabular}{|c|c|c|c|c|c|c|}
\hline t value & t Sig. & Standardized $\beta$ eta & $\mathbf{R}$ & $\mathbf{R}^{2}$ & F value & F Sig. \\
\hline 2.403 & .033 & .570 & .570 & .325 & 5.773 & .033 \\
\hline
\end{tabular}

Table 7 shows that there is statistically significant impact of board of directors' independence effect on accounting disclosure of service companies in Jordan by earnings per share (EPS) indicator at the significance level $(\alpha \leq 0.05)$, where (t) value was (2.403), by Sig. (0.033).

\subsection{The third sub-hypothesis}

$\mathrm{H}_{\mathrm{O} 1-3}$ : There is no statistically significant effect at the level of $(\alpha=0.05)$ of the ownership concentration on the accounting disclosure of service companies in Jordan with its indicators return on assets (ROA) and earnings per share (EPS).

\section{This hypothesis was tested in two stages}

The first stage: Examining the impact of ownership concentration on the accounting disclosure of service companies in Jordan according to the return on assets (ROA) index, using the simple linear regression test, and the following results were concluded:

\section{Table 8}

Results of simple linear regression to test the impact of ownership concentration effect on assets (ROA) indicator.

\begin{tabular}{|c|c|c|c|c|c|c|}
\hline t value & t Sig. & Standardized $\beta$ eta & $\mathbf{R}$ & $\mathbf{R}^{2}$ & F value & F Sig. \\
\hline 10.286 & .000 & .948 & $.948^{\mathrm{a}}$ & .898 & 105.796 & $.000^{\mathrm{a}}$ \\
\hline
\end{tabular}

a. Dependent Variable: ROA

b. Predictors: (Constant), ownership concentration

Table 8 shows that there is statistically significant impact of ownership concentration effect on accounting disclosure of service companies in Jordan by return on assets (ROA) indicator at the significance level $(\alpha \leq 0.05)$, where (t) value was (10.286), by Sig. (0.000).

The second stage: Examining the impact of ownership concentration on accounting disclosure for service companies in Jordan with the earnings per share (EPS) index using the simple linear regression test, and the following results were concluded:

Table 9

Results of simple linear regression to test the impact of ownership concentration effect on earnings per share (EPS) index

\begin{tabular}{cccccccc} 
t value & t Sig. & Standardized $\beta$ Reta & R & $\mathbf{R}^{2}$ & F value & F Sig. \\
\hline 6.974 & .000 & .896 & .896 & .802 & 48.632 & .000 \\
\hline
\end{tabular}

a. Dependent Variable: EPS

b. Predictors: (Constant), ownership concentration

Table 9 shows that there is statistically significant impact of ownership concentration effect on accounting disclosure of service companies in Jordan by earnings per share (EPS) indicator at the significance level $(\alpha \leq 0.05)$, where (t) value was (6.974), by Sig. (0.000).

According to the results of the two stages, we can conclude that: There is a statistically significant impact at the level of $(\alpha=0.05)$ of ownership concentration on the accounting disclosure of service companies in Jordan with its indicators (return on assets (ROA), earnings per share (EPS).

The previous mentioned can be explained by the fact that the ownership right meant the capital, reserves, and retained earnings, and as for deposits, they are the sum of deposits regardless of their type, whether they are current, savings, or future 
deposits. This ratio indicates the extent to which a commercial bank can rely on equity as a source of financing sources, and its ability to return deposits, indeed, the higher this percentage, the more depositors' funds will be secured.

There are also several indicators to measure profitability in commercial banks, perhaps the most important of which is the return on shareholders and return on equity (ROE), which indicates the efficiency of investment and operational decisions in commercial banks, and the provide the cash liquidity in banks is an important factor through which commercial banks can fulfill their short-term obligations, and through them, it can reduce the risks that they may be exposed to in liquidity shortage status.

\section{Recommendations}

1- Increase accounting disclosure for companies by encouraging investment in service companies listed on the Amman Stock Exchange, and providing cash liquidity that helps the executive department to invest in the investment projects.

2- Working on setting investment laws and legislations that create an investment environment for shareholders, thus, increase domestic investment in Jordan.

3- Working to increase the effectiveness of the Board of Directors in selecting and monitoring the executive department and exercising their role in developing the wealth of shareholders in a manner that ensures the balance of interests between all parties.

4- The necessity to work to find fair foundations and rules and apply them equally to all shareholders, in a manner that ensures the preservation of all shareholders' rights.

5- Granting broader powers to stakeholders, especially the minority of shareholders, in exercising the regulator role over management, which contribute to supporting and encouraging investors.

6- Working to increase the level of disclosure and transparency in financial reports and their availability to all stakeholders to give shareholders security for their money with sufficient independence for the board of directors.

\section{References}

Al Nuaimi, A \& Al-Ali, Manhal. (2020). Internal Control under Corporate Governance (First Edition). Amman, Jordan: Wael Publishing and Distribution House.

Al-Aqra, S. (2019). The governance of Sharia supervisory bodies in Yemeni Islamic financial institutions in light of the international standards issued by (IFSB) (AAOIFI). Journal of the Islamic University of Economic and Administrative Studies, 27(4), 129-172.

Al-Foley, F. (2018). The effect of the characteristics of the board of directors on the quality of profits as a measure of the quality of financial reports - an empirical study. House System Magazine, 2 (1), 112-127.

Al-Qahtani, M. (2015). Measuring and managing performance in the government sector in the Kingdom of Saudi Arabia. The second conference of public administration and administrative development institutes in the countries of the Cooperation Council for the Arab States of the Gulf. 63-117. Retrieved from https://dr.alameri.com

ALtawalbeh, M. (2020). Corporate Governance Mechanisms and Firm's Performance - Evidence from Jordan. Accounting and Finance Research, 9 (2), 11-22.

Al-Wazzani, K. (2019, February 17). Services sector. Headquarters newspaper. Retrieved from https://maqar.com

Barmawi, Y. (2019, March 17). Investing in the transport sector. Al-Destur Magazine. Retrieved from https://www.addustour.com/articles/1063877

Batayneh, H., Abd, S. \& Sweden, M. (2019). The impact of ownership structure and institutional governance on the financial performance of the listed Jordanian companies. Jordanian Journal of Business Administration, 15 (1), 96-119.

Brody, M. \& Abdul Latif, M. (2016). The effect of the characteristics of the Board of Directors and the Audit Committee on the accounting disclosure of the companies: An experimental study on the companies that formed the CAC 40 index from 2010 to 2014. Al-Wahat Journal for Research and Studies, 9 (2), 690-721.

Buertey, S., Sun, E. J., Lee, J. S., \& Hwang, J. (2019). Corporate social responsibility and earnings management: The moderating effect of corporate governance mechanisms. Corporate Social Responsibility and Environmental Management, 27 (1), 256-271.

Khudair, A. (2020). Analyzing the relationship between human capital and economic growth in the Iraqi economic environment. ALKut Journal of Economic and Administrative Sciences, 12 (36), 163-184.

Kieso, D. E., Weygandt, J. J., \& Warfield, T. D. (2020). Intermediate accounting IFRS. $4^{\text {th }}$.edition. USA: John Wiley \& Sons.

Nasr, S. (2020). The impact of the added value of accounting information systems on the financial performance of the Jordanian industrial companies listed on the Amman Stock Exchange. Journal of the Islamic University of Economic and Administrative Studies, 28(1), 134-159.

OECD. (2004). OECD Principles of Corporate Governance, OECD Publications Service, France. https://www.oecd.org

OECD. (2014). Risk Management and Corporate Governance, Corporate Governance, OECD Publishing. https://www.oecd.org

OECD. (2015). G20/OECD principles of corporate governance, OECD Report to G20 Finance ministers and central bank governors, OECD Publications Service. https ://www.oecd.org 
Rashwan, A. (2017). Analyzing the relationship between the application of corporate governance and the governance of information technology and its impact on increasing the quality of accounting information. Journal of Financial, Accounting, and Administrative Studies, 8(1), 112-138.

Salihat, N., Shabita, M., Zaabi, M. \& Al-Omari, M. (2020). The effect of the structure and composition of the board of directors on the quality of the profits of Jordanian commercial banks. Jordanian Journal of Applied Sciences. Applied Science Private University, 22(1), 1-16.

Samour, M \&. Dergham, M. (2020). The Impact of the Components of the Ownership Structure on Agency Costs for Banks Listed on the Palestine Exchange - An Empirical Study. Journal of the Islamic University of Economic and Administrative Studies, 3(28), 1-20.

Securities Commission. (2017). Corporate Governance Instructions for Listed Joint Stock Companies. Amman Jordan. Retrieved from https://jsc.gov.jo

Shahwan, T. \& Habib, A. (2020). Dose the efficiency of corporate governance and intellectual capital affect a firm's financial distress? Evidence from Egypt. Journal of intellectual capital, 21(3), 403-430.

Shakhatra, M. K. \& Obada, I. (2020). Evaluating the performance of the Jordanian Islamic banks using financial ratios: a comparative study (2002-2017). Journal of the Islamic University of Economic and Administrative Studies, 28(3), 262289.

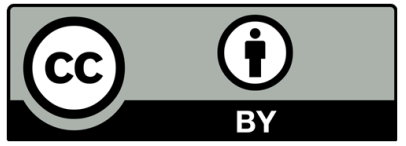

(C) 2021 by the authors; licensee Growing Science, Canada. This is an open access article distributed under the terms and conditions of the Creative Commons Attribution (CC-BY) license (http://creativecommons.org/licenses/by/4.0/). 